logos_i_ethos_2019_2_(50), s. 179-198

DOI: http://dx.doi.org/10.15633/lie.3484

\title{
Łukasz Mścisławski
}

https://orcid.org/0000-0003-0195-9064

Politechnika Wrocławska

\section{Przyczynek do badań nad myślą Czesława Białobrzeskiego: wizja relacji między nauką i religią}

Pierwsze dekady XX wieku, do wybuchu II wojny światowej, stanowią okres ${ }^{1}$, w którym można, jak się wydaje wyróżnić by użyć systematyki Dominique’a Lamberta $^{2}$ - zasadniczo dwie postawy w zakresie relacji nauka-religia. W szczególny sposób zaznacza się zatem postawa konfliktu albo daleko posunięty dyskordyzm (by podkreślić zupełnie różne płaszczyzny

dr Łukasz Mścisławski OP - pracownik badawczo-dydaktyczny Studium Nauk Humanistycznych i Społecznych Politechniki Wrocławskiej, wykładowca Kolegium Międzyobszarowych Studiów Interdyscyplinarnych Uniwersytetu Wrocławskiego i Kolegium Filozoficzno-Teologicznego Polskiej Prowincji Dominikanów, w 2011 roku obronił doktorat na Uniwersytecie Papieskim Jana Pawła II w Krakowie (Strukturalne i konceptualne zagadnienia teorii kwantów w świetle badań nad kwantowa grawitacją Chrisa Ishama). Do jego szczególnych zainteresowań badawczych należą filozoficzne implikacje teorii fizycznych, zwłaszcza w ujęciu historycznym.

1 W odniesieniu do wspomnianego okresu trzeba podkreślić, że wskazane byłyby znacznie szersze niż dotychczasowe badania w zakresie relacji nauka-wiara na ziemiach polskich. Trzeba przyznać, że powstanie fundamentalnych dla współczesnej fizyki teorii, tzn. ogólnej teorii względności i mechaniki kwantowej, nie wywołało szczególnie wielkich debat w zakresie wspomnianych relacji. Prawdziwym punktem zapalnym okazała się w tym względzie teoria ewolucji. Doskonałym opracowaniem tej tematyki jest: P. Polak, Spór wokół teorii ewolucji sprzed stu lat, „Zagadnienia Filozoficzne w Nauce" 41 (2007), s. 56-90.

2 Bardzo dobre omówienie relacji nauka-wiara (religia), zwłaszcza prezentację cech charakterystycznych modelu Lamberta można znaleźć w: S. Wszołek, Racjonalność wiary, Kraków 2003. Istnieją oczywiście także inne modele tych relacji, por. zwłaszcza: I. G. Barbour, Ways of Relating Science and Theology, w: Physics, Philosophy, and Theology: A Common Quest for Understanding, ed. G. V. Coyne S.J. i in., Vatican City State 1988, s. 21-48. 
poznawcze), lub jakiegoś rodzaju dążenie do integryzmu (z niewielką obecnością innych postaw). W przypadku badań dotyczących myśli Czesława Białobrzeskiego ${ }^{4}$ sprawa wydaje się stosunkowo prosta, między innymi przez dość jasne deklaracje warszawskiego fizyka. Jednakże uwypuklenie specyficznego charakteru jego refleksji nie jest łatwe, gdyż poczynione przez niego uwagi, dotyczące tej tematyki, są rozproszone w wielu źródłach. Jest to refleksja nietypowa, najbliższa - co zostanie przedstawione - postawie eksplikacji ${ }^{5}$, co czyni ją pewnym stopniu przeciwną wspomnianym już tendencjom. Białobrzeski jest świadom, że na fizykę, jako podstawową i najściślejszą naukę o świecie zewnętrznym, powołują się w gruncie rzeczy wszystkie kierunki myśli walczące z religią lub agnostyczne $e^{6}$.

Przy omawianiu poglądów warszawskiego fizyka na temat relacji nauka-religia warto zwrócić uwagę to, że mamy tu do czynienia z myślicielem, który w sposób świadomy usiłuje niezwykle precyzyjnie budować zwarty system opisujący rzeczywistość ${ }^{7}$. Pełne opracowanie osiągnięć Białobrzeskiego nie zostało jeszcze dokonane, i przekroczyłyby ramy niniejszej pracy, jakkolwiek jest to niewątpliwie zadanie,

3 Przykład takiego integryzmu podaje sam Białobrzeski, wspominając o próbie „pogodzenia” nauki z religią przez Ernsta Haeckla. Zaznacza przy tym, że próba ta zakończyła się zupełnym fiaskiem właśnie na skutek rozwoju nauki (fizyki), która zrujnowała pieczołowicie rozwijany przez niemieckiego biologa system niepodważalnych prawd (opartych, co ciekawe, na fizyce właśnie). Zob. C. Białobrzeski, Religia i nauka, „Nauka Polska. Jej potrzeby, organizacja i rozwój” 13 (1930), s. 3.

4 Czesław Białobrzeski (31.08.1878-12.10.1953), wybitny polski fizyk teoretyk, którego największym osiągnięciem było wyjaśnienie stanu równowagi gwiazd, czego dokonał przed Eddingtonem. Jest znany także jako utalentowany popularyzator nauki. Jego wkład w rozwój prac doświadczalnych i teoretycznych z zakresu fizyki, w odbudowującej się Polsce w dwudziestoleciu międzywojennym oraz po II wojnie światowej jest trudny do przecenienia. Jest również bardzo oryginalnym myślicielem z zakresu filozofii przyrody.

5 Eksplikacja jest sytuacją, w której szanuje się odmienność metodologiczną nauki i religii (teologii), jednocześnie podtrzymując przekonanie, że wzajemne oddziaływanie jest możliwe i jest faktem. Por. S. Wszołek, Racjonalność wiary, dz. cyt., s. 21-23.

${ }^{6}$ Zob. C. Białobrzeski, Religia i nauka, dz. cyt., s. 1.

7 Można go więc nazwać - choć to budzi zapewne różne skojarzenia - myślicielem systemowym, w tym jednak znaczeniu, że dąży on do zbudowania zwartego systemu opisującego rzeczywistość. 
które miałoby wielkie znaczenie zarówno filozoficzne, jak i historyczne. Na niektóre aspekty w myśli warszawskiego fizyka zwracano już uwa$\mathrm{gę}^{8}$. W niniejszym opracowaniu cel jest znacznie skromniejszy, a jest nim uwypuklenie pewnych szczególnych cech myślenia Białobrzeskiego o fenomenie religii. Wspomniane już myślenie dążące do wypracowania spójnego systemu odzwierciedla się także w refleksji dotyczącej problemu relacji nauka-religia. Wypada zatem przedstawić - opierając się na słowach samego autora - subtelną konstrukcję intelektualną, wewnątrz której znalazło się miejsce również na relacje między nauką a religią ${ }^{9}$.

Bardzo ważną rolę w tych relacjach odgrywają - zdaniem warszawskiego fizyka - pewne punkty styczne, w których dochodzi do zbliżenia między tymi oboma sferami ludzkiej działalności. Jednym $\mathrm{z}$ takich punktów, który można by określić mianem fundamentalnego, jest - zdaniem Białobrzeskiego - doświadczenie tajemnicy rzeczywistości, swoistego misterium przedmiotu badań naukowych ${ }^{10}$. Nie ogranicza się on jednak do wskazania tylko tego jednego punktu, podkreślając znaczenie także innych, niekiedy nieoczekiwanych, co zostanie zaprezentowane w dalszej części niniejszej pracy.

\section{Nauka a religia - punkty styku}

Lepsze zrozumienie poglądów Białobrzeskiego w zakresie relacji nauka-religia daje uwzględnienie podstawowych założeń filozoficznych warszawskiego fizyka. W Szkicach autobiograficznych podkreśla on:

8 Zwracano - przykładowo - uwagę na jego doktrynę jako filozofia przyrody. Por. np. S. Sawicki, Cz. Białobrzeski jako filozof przyrody, „Zagadnienia Filozoficzne w Nauce” 7 (1985), s. 28-42.

9 Istotna jest tutaj uwaga, że zasadniczo praca niniejsza nie będzie dotyczyć poglądów przeciwnych, o ile sam Białobrzeski o tym nie wspomina. Niewątpliwie cenne byłoby skonfrontowanie jego poglądów z którymś z uczonych o odmiennym stanowisku w sprawach relacji nauka-religia, niemniej wydaje się, że to zadanie najlepiej byłoby podjąć w osobnym opracowaniu.

10 Zob. C. Białobrzeski, Religia i nauka, dz. cyt., s. 2. 
W zagadnieniach teorji poznania zajmuję stanowisko realistyczne, które uznaje istnienie rzeczywistości niezależnej i odmiennej od świadomości ludzkiej. [...] Uderzającem jest zupełne niemal wyeliminowanie pierwiastków zmysłowych z podstawowych pojęć fizyki i oparcie jej na istnościach pozazmysłowych.

[...] W stosunku do istoty bytu jestem zwolennikiem kierunku spirytualistycznego, uznającego, iż poza zjawiskami przyrody ukrywa się, jako ich podstawa, byt pokrewny naszej duszy, której można przypisywać cechy substancji lub uważać poprostu za rozwijający się w czasie zespół objawów psychicznych. Nie widzę powodu do odrzucania pojęcia o duszy jako substancji ${ }^{11}$.

Powyższe deklaracje są istotne dla zrozumienia całości konstrukcji myślowej, w której Białobrzeski osadza swoją wizję relacji między nauką a wiarą. Pewne ogólne cechy nauki - jego zdaniem ${ }^{12}$ - sprawiają, że możliwe jest spotkanie między nią a religią. Po pierwsze zatem, kładzie on nacisk na fakt, że rozwój fizyki prowadzi do eliminacji odniesień do doświadczeń zmysłowych (przynajmniej w zakresie codziennego doświadczenia). Na jej gruncie bowiem używa się odniesień do struktur lub obiektów, które nie mają bezpośredniego odniesienia do sfery zmysłów (niewątpliwie koronnym przykładem będą tutaj trudności interpretacyjne związane $z$ użyciem funkcji falowej w mechanice kwantowej). Po drugie, podkreśla on fakt, iż elementem konstytutywnym człowieka jest pewna rzeczywistość, pokrewna podstawie rzeczywistości przyrodniczej, która nie ma charakteru materialnego. Trzeba jednakże tutaj - w odniesieniu do poglądów Białobrzeskiego - poruszyć jedną ważną kwestię, którą jest pytanie o to, czy natura procesów psychicznych (i fakt, że są to procesy dynamiczne) różni się od tego, co warszawski

11 C. Białobrzeski, Szkic autobiograficzny i uwagi o twórczości naukowej, „Nauka Polska” 6 (1927), s. 49-76. We wszystkich cytatach pozostawiono pisownię oryginalną.

12 Szczegóły dotyczące rozumienia nauki u Białobrzeskiego omawia np. L. Motycka, Czesław Białobrzeski's Conception of Science, w: Polish Philosophers of Science and Nature in the 20th Century, ed. W. Krajewski, Amsterdam-New York. Tematyka ta jednak wymaga, jak się wydaje, szerszego opracowania, biorącego pod uwagę choćby popularyzatorskie działania Białobrzeskiego, czy też jego refleksję dotyczącą wpływu nauki na życie społeczne. 
fizyk określa mianem sfery duchowej - i jak ta ostatnia jest przez niego rozumiana ${ }^{13}$. Białobrzeski - jak sugerują przytoczone słowa ze Szkicu autobiograficznego - wydaje się traktować zjawiska psychiczne jako fenomeny niezwiązane $z$ materią, jednakże bez precyzowania ich natury. Fakt, że warszawski fizyk przyjmuje istnienie rzeczywistości pozamaterialnej - niezależnie od tego, czy jego rozumienie procesów psychicznych jest prawidłowe czy też niezupełnie ${ }^{14}$ - wydaje się wynikać przede wszystkim z jego krytyki monizmu, przedstawionej w pracy Nauka $i$ kultura $^{15}$. Warto przy tym zauważyć, że - jak wynika z samych jego słów - nie stroni on od refleksji metafizycznej, zauważając przy tym pewną niekonsekwencję pozytywizmu. Niekonsekwencja ta - jak nietrudno się domyśleć - dotyczy próby wyrugowania przez pozytywistów tez metafizycznych, jednakże działania te, zdaniem Białobrzeskiego, bazują także na przesłankach metafizycznych ${ }^{16}$.

Z powyższej deklaracji oraz niewątpliwej otwartości na spekulację metafizyczną można, jak się zdaje, wyciągnąć wniosek, że fizyk uważa za możliwe poznawcze ujęcie wspomnianej podstawy rzeczywistości. Oznacza to wyjście poza domenę ściśle kontrolowaną przez narzędzia naukowe. Można tu postawić zarzut, że wówczas stwierdzenia dotyczące eksplorowanej przez badania metafizyczne warstwy rzeczywistości stanowią zasadniczo stwierdzenia swoiście rozumianej, bardzo fundamentalnej wiary. Białobrzeski uważa, że rzeczywiście tak jest, niemniej wskazuje także, że w swej warstwie fundamentalnej nauka i religia funkcjonują w bardzo podobny sposób. Czerpiąc swój materiał poznawczy

13 Zob. C. Białobrzeski, Rzeczywistość w ujęciu przyrodoznawstwa, „Przegląd Naukowy i Pedagogiczny" 1 (1916) nr 1, s. 29.

14 Wyrażając rzecz precyzyjniej, Białobrzeski uważa, że można napotkać opinie, według których uważa się za fakt uzasadniony doświadczalnie, że zjawiska psychiczne są funkcją (działania) mózgu. Stwierdza, że takie opinie należy uważać za jakiegoś rodzaju nieporozumienie, gdyż funkcji tego rodzaju (przebiegów psychicznych) nie zna ani fizyka, ani chemia - a więc dziedziny, w których zakotwiczone są wszelkiego rodzaju wypowiedzi dotyczące doświadczalnych zagadnień związanych z procesami psychicznymi. Zob. C. Białobrzeski, Rzeczywistość w ujęciu przyrodoznawstwa, dz. cyt., s. 30 .

15 C. Białobrzeski, Nauka i kultura, w: Kultura i nauka, praca zbiorowa, Warszawa 1937, s. 4-7.

16 Zob. C. Białobrzeski, Rzeczywistość w ujęciu przyrodoznawstwa, dz. cyt., s. 29-30. 
$\mathrm{i}$ inspirację $\mathrm{z}$ doświadczenia, nauka jest typem poznania, który nieustannie dokonuje zmian w swych podstawach. Z jednej strony więc autorytet nauki (zwłaszcza w czasach, w których przyszło żyć Białobrzeskiemu) jest ogromny, z drugiej jednak strony, warszawski fizyk jest świadom, że taka sytuacja daje też podstawy do pewnego sceptycyzmu wobec przedsięwzięcia naukowego. W kontekście porównań z religią zauważa wprost:

[...] Myślenie musi zatem w każdej chwili robić wybór między twierdzeniem i negacją, innemi słowy poznanie zawiera w sobie akty wiary, czyli w swych źródłach najgłębszych styka się religią.

Jest to jeden z podstawowych punktów wspólnych dla przedsięwzięć, takich jak nauka i religia. Naukę rozumie Białobrzeski - oprócz innych dookreśleń - jako intelektualny wysiłek zmierzający do poznania Prawdy, rozumianej przez niego jako wartość duchowa. Zauważa przy tym, że - mimo wielkich deklaracji - cel ten wcale jeszcze nie został osiągnięty, nauka nie posiada ostatecznego wyjaśnienia rzeczywistości podległej jej badaniu ${ }^{17}$. Co więcej - jego zdaniem - rozstrzygnięcie na podstawie swoistego wyznania wiary, dokonuje się także w matematyce w zakresie badań nad pojęciem nieskończoności ${ }^{18}$. Sam fakt zbliżenia się nauki i religii w przytoczonym przez niego przykładzie wydaje się być bardzo zbieżny z kwestiami granicznymi, a zwłaszcza paralelami metodologicznymi, które Julian Barbour podkreśla w swojej systematyce relacji nauka-wiara, w odniesieniu do dialogu między nimi. Sytuację, o której wspomina Białobrzeski, powołując się na Henriego Poincarégo, można tutaj scharakteryzować jako pośrednie powiązanie, jakiegoś rodzaju fundamentalne podobieństwo w obu rodzajach ludzkiej aktywności i postawie ${ }^{19}$. Warszawski fizyk uzupełnia dodatkowo swe analizy

17 Zob. C. Białobrzeski, Religia i nauka, dz. cyt., s. 3.

18 Białobrzeski odwołuje się tu najprawdopodobniej do: H. Poincaré, Dernières pensées, Paris 1913, a w zasadzie do dwóch rozdziałów tej pozycji: La Logique de l'Infiniti oraz Les Mathématiques et la Loqique.

19 Por. I. G. Barbour, Ways of Relating Science and Theology, w: Physics, Philosophy, and Theology: A Common Quest for Understanding, dz. cyt., s. 33-40. 
o spostrzeżenie, iż praca naukowa jest w swej istocie poszukiwaniem motywów do wierzenia, tak aby każdy poprawnie posługujący się rozumem człowiek mógł czuć się przez nie przekonanym ${ }^{20}$. Zważywszy na powyższe, naukę, która miałaby - wedle wzorców najszerzej rozumianego pozytywizmu - być ostateczną, niezawodną instancją pokonywania wszelkich możliwych trudności i dostarczać prawdziwego oglądu rzeczywistości, należałoby uznać za przedsięwzięcie wymagające analogicznego aktu wiary, jak ma to miejsce w religii. Dodatkowo - świadom potęgi tej instancji jako wytrawny fizyk - Białobrzeski zauważa, że charakteryzuje się ona także nieodłączną, wewnętrzną słabością, która wynika z faktu, że jest wytworem duchowym człowieka (jako bytu niedoskonałego). Na podstawie rozwoju fizyki, zauważa on także, iż im więcej jest etapów pośrednich na drodze od danych zmysłowych do ostatecznej, ogólnej teorii, tym mniejsza wydaje się być siła przekonywania tej ostatniej. Jest jasne, że im ogólniejsze teorie, docierające do coraz głębszych warstw rzeczywistości, im więcej zjawisk opisujące, tym bardziej w swym sformułowaniu oddalają się od prostych danych zmysłowych oraz intuicji na nich opartych ${ }^{21}$. Niemniej, jak zauważa warszawski fizyk, nie należy wyrzekać się nadziei, że budując systemy pojęciowe sięgające tych właśnie warstw, będzie można ostatecznie dotrzeć do prawd fundamentalnych, wiecznych. Ta nadzieja jest jednak - według niego - w „wysokim stopniu aktem wiary" ${ }^{22}$. Można tutaj dostrzec zatem kolejne dwa punkty styku nauki i religii. Pierwszy z nich to nadzieja na możliwość dotarcia do ostatecznych prawd o rzeczywistości, w tym tych wiecznych. Drugim jest natomiast wiara, że jest to przedsięwzięcie możliwe do zrealizowania, jakkolwiek Białobrzeski nie próbuje określać, w którym

20 Byłaby to zatem kolejna paralela metodologiczna.

21 Wystarczy wspomnieć tutaj ogólną teorię względności lub mechanikę kwantową. Białobrzeski przywołuje tu także opinię Borna, wedle której zasada przyczynowości w jej zwykłym rozumieniu traci jakiekolwiek znaczenie. Por. C. Białobrzeski, Religia i nauka, dz. cyt., s. 4. Należy dodać, że zwykłe - czyli zazwyczaj mechanicystyczne rozumienie zasady przyczynowości - zostało wypracowane w oparciu o intuicję bazującą na potocznym doświadczeniu oraz wzmocnione przez mechanikę newtonowską. W tej tematyce por. zwłaszcza: C. Białobrzeski, Nauka ścisła o przyrodzie na tle ogólnych wartości kultury, Kraków 1935, s. 12-20.

22 C. Białobrzeski, Religia i nauka, dz. cyt., s. 4-5. 
miejscu - w tym procesie - znajduje się nauka, jeśli chodzi o czasy jemu współczesne ${ }^{23}$. Widać tutaj także przekonanie warszawskiego fizyka, że dotarcie do wspomnianych ostatecznych prawd, lub - jak określa je on sam - prawd wiecznych, jest możliwe, jeśli za punkt wyjścia przyjmie się badania naukowe. Nie twierdzi on jednak, że to dojście jest konieczne ani że każdy musi go dokonać, zwłaszcza jeśli zajmuje stanowisko odmienne od jego własnego ${ }^{24}$.

Jest bardzo interesujące, że Białobrzeski widzi również - w odniesieniu do fizyki (jemu) współczesnej - możliwości, które stwarza ona dla przerzucenia jakiegoś rodzaju pomostu między nauką (pozytywną) a światem wartości. Podkreśla on szczególnie dwie konsekwencje, które wynikły z rozwoju fizyki. Pierwszą z nich jest świadomość, że fałszywe jest przekonanie, iż nauki przyrodnicze dostarczają prawd ostatecznych i bezwzględnych. Konsekwencja druga to rozerwanie żelaznego uścisku mechanicznej przyczynowości, której dokonała zwłaszcza mechanika kwantowa. To natomiast prowadzi warszawskiego fizyka do wniosku, że rozwój sytuacji w naukach przyrodniczych i wypracowanie zupełnie nowych schematów pojęciowych doprowadziło do usunięcia sztucznego, zaproponowanego przez Kanta rozwiązania antynomii konieczności i przypadku. Dostrzega tu więc Białobrzeski wielką rolę ewolucji pojęć i schematów pojęciowych, która dokonuje się w związku z rozwojem dyscyplin naukowych. Spostrzeżenie to wydaje się stanowić zarys możliwości jakiegoś rodzaju oddziaływania przez oczyszczanie i rozjaśnianie pojęć. Co więcej, nie wyciągając zbyt daleko idących wniosków, warszawski fizyk sugeruje, że postęp w naukach przyrodniczych dostarcza nowego i trudnego do przecenienia materiału, jeśli chodzi o możliwość

23 Białobrzeski jest także świadom, że pomimo skuteczności zastosowania matematyki w opisie warstw podległych badaniom w zakresie fizyki, jest to możliwe w zasadzie tylko dlatego, że o tej rzeczywistości niewiele wiadomo. Tym samym można przyjąć, że podziela on pogląd B. Russela w tym względzie (na niego zresztą się powołuje, por. C. Białobrzeski, Religia i nauka, dz. cyt., s. 5). Należy jednakże przy tym wspomnieć, iż Białobrzeski dostrzega siłę, piękno, precyzję i zwartość matematycznego opisu zjawisk przyrodniczych, czemu dał wyraz m.in. w odczycie wygłoszonym 22 czerwca 1935 roku, na posiedzeniu Polskiej Akademii Umiejętności w Krakowie. Por. C. Białobrzeski, Nauka ścista o przyrodzie na tle ogólnych wartości kultury, dz. cyt., s. 5.

24 Zob. C. Białobrzeski, Religia i nauka, dz. cyt., s. 2. 
utworzenia czegoś w rodzaju syntezy filozoficznej. Zdaje sobie sprawę, że nie będzie ona ostateczna, właśnie ze względu na nieustanny rozwój nauk, niemniej podkreśla wagę wysiłku w dążeniu do uzyskania jakiegoś rodzaju uporządkowania ideowego oglądu rzeczywistości. Rolę tę uważa za niezwykle doniosłą, gdyż wymaga tego „równowaga duchowa każdego pokolenia” oraz umiejętność ujęcia w całość zasadniczych elementów „życia kulturalnego człowieka”25. Co więcej, twierdzi, że rozwój ten najprawdopodobniej odbije się także na światopoglądzie człowieka, który jest - według niego - wyrazem ogólnie rozumianej postawy człowieka wobec rzeczywistości ${ }^{26}$. Czy i jak wpłynie to na rozumową analizę treści religijnych - tego warszawski fizyk nie precyzuje. Jeśli jednak założyć, że taka analiza zakłada jakieś tło filozoficzne i zestaw pojęć, których człowiek używa w tym celu, wówczas sytuacja jest już nieco odmienna. Białobrzeski podkreśla bowiem (jakkolwiek nie w bezpośrednim związku z religią), że przy wyciąganiu filozoficznych wniosków, bazujących na osiągnięciach nauk przyrodniczych, należy zachować daleko idącą ostrożność ${ }^{27}$.

\section{Religia jako usensownienie nauki?}

W tym miejscu wypada zaprezentować koncepcję religii, którą posługuje się Białobrzeski, zestawiając ją z nauką i wskazując na wspomniane już punkty spotkania między nimi. Zasadniczo - analizując relacje między nauką a religią - skupia się on na określeniu bardzo ogólnym, opierając się na propozycji Williama Jamesa, aby rozumieć religię jako podłoże

25 Zob. C. Białobrzeski, Nauka i kultura, dz. cyt., s. 27-29. Białobrzeski jest szczególnie wyczulony na kwestie uporządkowania światopoglądu i systemu idei, którego brak prowadzi do zamieszania i stanu rozterki ducha ludzkiego. Ten stan nie jest dla niego normalnym stanem człowieka może doprowadzić do niemałego zamieszania w sferze społecznej, co ma niekiedy katastrofalne skutki. Zob. np. C. Białobrzeski, Rzeczywistość w ujęciu przyrodoznawstwa, „Przegląd Naukowy i Pedagogiczny" 1 (1916) nr 1, s. 29.

26 Zob. C. Białobrzeski, Nauka ścisła o przyrodzie na tle ogólnych wartości kultury, dz. cyt., s. 11.

27 Zob. C. Białobrzeski, Nauka ścisła o przyrodzie na tle ogólnych wartości kultury, dz. cyt., s. 21. Nie sposób tutaj nie zauważyć, że bardzo podobne (do wyżej wymienionych) idee pojawiają się u Michała Hellera. Zob. np. M. Heller, Nowa fizyka i nowa teologia, Kraków 2015. 
wiary $\mathrm{w}$ istnienie porządku niewidzialnego, w którym znajdują uzasadnienie tajemnice porządku naturalnego. Wprowadza więc tutaj - za Jamesem - porządek natury, związany z doświadczeniem zmysłowym, oraz świat nadnaturalny, w odniesieniu do którego znaczenia nabiera ziemska egzystencja człowieka ${ }^{28}$. Tego rodzaju spojrzenie - zwłaszcza w kontekście faktu, że Białobrzeski nie widzi powodu, by odrzucać istnienie świata pozamaterialnego - w sposób dość nieoczekiwany - pomaga warszawskiemu fizykowi nadać sens działalności naukowej, dodatkowo dość precyzyjnie umiejscawiając naukę w całokształcie funkcjonowania człowieka.

Pierwszym krokiem jest tutaj stwierdzenie, że nauka sama w sobie nie znajduje swego usprawiedliwienia. Zakładając, że nauka jest poszukiwaniem prawdy, to po pierwsze Białobrzeski zauważa, iż taka ocena nauki nie jest zbudowana na dowodzeniu naukowym, lecz jest „aktem swobodnej decyzji umysłu, który wierzy w ideał prawdy" ${ }^{29}$. Po drugie, jeśli przyjmiemy taki stan rzeczy, wówczas trzeba uznać, że istnieją wartości, określane przez Białobrzeskiego mianem duchowych, które różnią się od wartości poznawczych, a do których nauka (rozumiana jako nauka pozytywna) nie ma dostępu ${ }^{30}$. Sam akt wiary $w$ istnienie Prawdy jest jak sama nazwa wskazuje - aktem wiary, sięgającym wspomnianej już sfery pozamaterialnej. Można ponadto w tym właśnie miejscu postawić kolejne pytanie, a brzmi ono: jaki jest - według Białobrzeskiego - status Prawdy jako wartości duchowej? Czy jest on taki sam, jak pozostałych dwóch klasycznych idei (czy wartości), mianowicie Piękna i Dobra? Odpowiedź na to pytanie nie pada ze strony warszawskiego fizyka bezpośrednio, podziela on jednak $\mathrm{w}$ tym względzie - jak się zdaje - opinię Poincarégo, że poszukując piękna, znajdujemy prawdę ${ }^{31}$, co mogłoby

28 Zob. C. Białobrzeski, Religia i nauka, dz. cyt., s. 9. Białobrzeski odwołuje się tutaj do eseju: W. James, The Will to Believe, „he New World” 5 (1896), s. 327-347. Wzmacnia swoje stanowisko, stwierdzając, że obecnie (w czasach jemu współczesnych) fizyka nieodwołalnie wkroczyła w dziedzinę pozazmysłową. Stąd opieranie się w budowaniu stwierdzeń dotyczących struktury ontologicznej rzeczywistości na pojęciach odnoszących się jedynie do wrażeń zmysłowych uważa on za problematyczne. Zob. C. Białobrzeski, Religia i nauka, dz. cyt., s. 6.

29 Zob. C. Białobrzeski, Religia i nauka, dz. cyt., s. 7.

30 Zob. C. Białobrzeski, Nauka i kultura, dz. cyt., s. 24.

31 Zob. C. Białobrzeski, Religia i nauka, dz. cyt., s. 15. 
sugerować pewne pokrewieństwo. Białobrzeski jednoznacznie stwierdza, że nauka ma na celu poznanie Prawdy ${ }^{32}$. Jak się jednak rzeczy mają, jeśli chodzi o inne (jak je określa warszawski fizyk) wartości duchowe?

Kolejnym krokiem, jeśli chodzi o umiejscowienie nauki w całokształcie działalności człowieka, jest zwrócenie uwagi na to, że Białobrzeski jak już wspomniano - zauważa, iż wartości duchowe inne niż poznawcze pozostają zupełnie poza zasięgiem nauki pozytywnej ${ }^{33}$. Podkreślenia w kontekście tej tezy wymaga jego stwierdzenie, że jest możliwe przerzucenie jakiegoś rodzaju pomostu między nauką pozytywną a światem wartości. Szansę tę upatruje warszawski fizyk właśnie w rozwoju fizyki ${ }^{34}$. Mimo to jednak, Białobrzeski wydaje się zdawać sobie sprawę z tego, iż potrzeba innego rodzaju dostępu do wartości duchowych. Konieczność takiego dostępu widzi jako konsekwencję faktu, że nauka jako taka w ogóle nie wypowiada się na temat kwestii, które samo życie stawia jako najważniejsze. Odwołując się do wypowiedzi Friedricha Gaussa, stwierdza, że są to przede wszystkim kwestie etyki, stosunku do Boga, czy też sensu ludzkiej egzystencji (przeznaczenia człowieka). Co więcej, nauka pozytywna jako taka nie potrafi sama z siebie wskazać celów, którym powinna być podporządkowana działalność człowieka, w szczególności zatem także wskazać, z jakiego powodu i w jakim celu człowiek miałby w ogóle uprawiać naukę ${ }^{35}$. Trudno tutaj jednak o stwierdzenie, jak - według Białobrzeskiego - człowiek miałby nabrać przekonania, że uprawianie nauki jest zajęciem, które warto podjąć. Jeśli przyjąć, że jest czymś dobrym dążenie do prawdy - a więc, że zasadniczy cel uprawiania nauki jest czymś wartym wysiłku - wówczas religia, wraz ze swoimi kompetencjami w zakresie zagadnień etycznych (a zatem orzekania o tym, co jest dobre, a co złe), miałaby jakiegoś rodzaju szanse na wskazanie sensu takiego wysiłku, widząc go jako jakieś dobro, czy też wartość godną realizacjii ${ }^{36}$.

32 Zob. C. Białobrzeski, Religia i nauka, dz. cyt., s. 2.

33 Zob. C. Białobrzeski, Nauka i kultura, dz. cyt., s. 24.

34 Zob. C. Białobrzeski, Nauka i kultura, dz. cyt., s. 28.

35 Zob. C. Białobrzeski, Religia i nauka, dz. cyt., s. 5-8.

${ }^{36}$ Ściślej rzecz ujmując, Białobrzeski widzi wartości duchowe jako możliwe do usprawiedliwienia tylko w kontekście religii. Zob. C. Białobrzeski, Szkic autobiograficzny i uwagi o twórczości 
Wydaje się jednak, że problem istnienia zagadnień etycznych i swoistej ślepoty nauki pozytywnej na ten fakt, prowadzi go do wniosku, że potrzeba tutaj także innego rodzaju poznawczego dostępu do rzeczywistości wartości duchowych, a zatem jakiegoś znacznie szerszego ujęcia poznawczego całości rzeczywistości. Takie całościowe, racjonalne ujęcie stosunku człowieka do świata nazywa Białobrzeski mądrością. W kontekście zagadnień etycznych warto wskazać, że fizyk zdaje sobie sprawę, że nauka dąży do stwierdzeń obiektywnych, pozbawionych elementu zaangażowania osobistego podmiotu poznającego. Jednakże człowiek pozostaje człowiekiem i znajduje się zawsze w sytuacji, która wpływa na jego egzystencję jako jednostki, ale też jako członka społeczności. Wspomniane, mądrościowe ujęcie rzeczywistości obejmuje według warszawskiego fizyka tę właśnie sytuację człowieka, włączając w to także jego los i zbawienie, które są szczególnym przedmiotem zainteresowania religii i jej refleksji mądrościowej, oraz jego (człowieka) prawa ${ }^{37}$. Podkreśla on także, że aby móc wypracować takie ogólne ujęcie rzeczywistości, potrzeba - w związku z dynamicznym rozwojem nauki - wypracować nową, systematyczną, syntezę filozoficzną, pozostającą w kontakcie z naukami ${ }^{38}$.

Białobrzeski zdaje sobie sprawę, że pomiędzy religią i nauką istnieje rozziew spowodowany faktem, że twierdzenia religii są niedowodliwe w sposób czysto naukowy. Jest tak z tego powodu, że mają one wspomniany już, mądrościowy charakter i nie da się tej różnicy przekreślićc ${ }^{39}$. Jednakże zauważa on także, że zarówno tezy mądrościowe religii, jak i sama działalność naukowa stanowią składowe mądrości. Człowiek zaś jest jednością, i może - poznając rzeczywistość przy pomocy nauki - stawiać także pytania o sens całości rzeczywistości, także jej celu. Wkracza tym samym w domenę religii. Jak zauważa Białobrzeski, między tymi dwoma biegunami istnieje swego rodzaju napięcie, i człowiek w swej poznaw-

naukowej, dz. cyt., s. 76. Temat ten zostanie poruszony w dalszej części pracy.

37 Zob. C. Białobrzeski, Religia i nauka, dz. cyt., s. 10.

38 Zob. C. Białobrzeski, Nauka i kultura, dz. cyt., s. 25.

39 Zob. C. Białobrzeski, Religia i nauka, dz. cyt., s. 11-13. Mimo to Białobrzeski wskazuje w swym wystąpieniu na próby sprowadzenia twierdzeń religii do twierdzeń wynikających z nauki pozytywnej, jak miało to miejsce choćby u wspomnianego przez niego Haeckla. 
czej aktywności w pewnym sensie oscyluje między nimi. Nie przekreśla to jednak faktu, że w umyśle ludzkim istnieje możliwość wyartykułowania zarówno tez religijnych, jak i naukowych i badania ich wzajemnych relacji oraz możliwości przenikania się czy tworzenia jakiegoś syntetycznego oglądu rzeczywistości. W tych wysiłkach kolejna wartość duchowa, a mianowicie Piękno, spełnia najbardziej doniosłą rolę, stwarzając możliwość dotarcia do Prawdy. Trzeba przyznać, że to bardzo atrakcyjne, a jednocześnie trudne ujęcie, jest bliskie eksplikacji Lamberta ${ }^{40}$.

\section{Osobiste poglądy Białobrzeskiego i... kontekst społeczny religii}

Warto w tym miejscu wspomnieć o osobistych poglądach Białobrzeskiego, zwłaszcza na temat religii. Uważa on zatem, że jest ona nieodzowną potrzebą większości ludzi, wynikającą ze świadomości kruchości ludzkiej egzystencji i jej uzależnienia od wyższego porządku. Porządek ten odsłania się jakoś dla ludzkiego poznania. Warszawski fizyk twierdzi, że właśnie dla uczonych, zaangażowanym w badanie tajemnic świata, to poznanie wyższego porządku ma szansę stać się czymś właściwym. Zauważa jednak, że niekoniecznie musi tak być, stało się to jednak jego udziałem. Podkreśla także, że wartość jednostki określają zasady moralne, którymi kieruje się ona w swoim postępowaniu. Jego zdaniem ostateczne uzasadnienie pojęcia dobra, powinności etycznej oraz w ogóle wartości duchowych może zostać odnalezione tylko w religii, która

40 Zob. C. Białobrzeski, Religia i nauka, dz. cyt., s. 14-15. Z najnowszych opracowań dotyczących problematyki styków nauki z religią (a ściślej: teologią), której poszczególne punkty styku, widziane są jednak z perspektywy teologa, godna polecenia jest praca: D. Lambert, Ryzykowne spotkanie teologii z nauką, Kraków 2018. Autor porusza w niej także m.in. wątki dotyczące celowości. Należy podkreślić, że kategoria celowości jako taka jest bardzo istotna dla Białobrzeskiego jako filozofa przyrody. W tej tematyce zob. zwłaszcza: C. Białobrzeski, Syntetyczny rozwój pojęć fizyki, „Przegląd Filozoficzny" 40 (1937) nr 1, Warszawa, 1937, s. 8-18; C. Białobrzeski, Podstawy poznawcze świata atomowego, Warszawa 1984. Z opracowań por. zwłaszcza: J. Twarowska, Zagadnienia z zakresu filozofii fizyki i filozofii przyrody u Czesława Białobrzeskiego, „Studia Philosophiae Christianae” 5 (1969) nr 2, s. 141-158; S. Sawicki, Cz. Białobrzeski jako filozof przyrody, dz. cyt., s. 28-42. 
traktuje Boga jako najwyższe dobro ${ }^{41}$. W kwestii pojęcia Boga zajmuje Białobrzeski stanowisko teistyczne, niemniej przyznaje, że ma pewną skłonność do nadawania teizmowi nuty panteizmu, którą uważa za charakterystyczną dla przyrodników ${ }^{42}$. Szczególnym wyrazem tej inklinacji wydaje się być - w kontekście poruszanej tematyki - kategoria potencjalności, którą wprowadza w ramach refleksji dotyczących filozoficznych implikacji mechaniki kwantowej i rozszerza na całość rzeczywistości, włączając w to także Boga Stwórcę. Określa Go jako Wszechpotencjalność, z której hierarchicznie wyrastają inne, najwyższe potencjały, będące niezależnymi istotami (formami) duchowymi. Z Wszwechpotencjalności miałaby także wyrastać potencjalność Wszechświata oraz dalsza hierarchia indywidualnych istot. Takie ujęcie sugerowałoby zależność tych potencjalności od Wszechpotencjalności, przy zachowaniu ich indywidualności i odróżnienia od niej ${ }^{43}$.

Warszawski fizyk zwraca także uwagę, że religia jest sprawą sumienia jednostki. Zauważa jednakże, że człowiek zawsze żyje w jakiejś społeczności i dąży do - jak to określa - duchowej wspólnoty z innymi ludźmi oraz do tworzenia powszechnych dóbr duchowych ${ }^{44}$ i tendencja ta znajduje swoje odzwierciedlenie w życiu religijnym. Ze wszystkich religii,

41 Zob. C. Białobrzeski, Szkic autobiograficzny i uwagi o twórczości naukowej, dz. cyt., s. 76.

42 Zob. C. Białobrzeski, Szkic autobiograficzny i uwagi o twórczości naukowej, dz. cyt., s. 75. Rodzi się tutaj pytanie, czy Białobrzeski byłby skłonny zaakceptować jedną z form panenteizmu (który oczywiście nie mógł być mu znany z racji swego późniejszego powstania - ukształtował się on w pełni już po śmierci Białobrzeskiego). Więcej na temat charakterystyki tego nurtu można znaleźć np. w: W. Wojtysiak, Panenteizm. W związku z poglądami Józefa Życińskiego, Charlesa Hartshorne’a i innych przedstawicieli zwrotu panenteistycznego, „Roczniki Filozoficzne” 60 (2012) nr 4, s. 313-337. Co ciekawe, Białobrzeski przyznaje, że w swej młodości sam skonfrontował się z poglądami antyreligijnymi, roszczącymi sobie pretensje do bycia naukowymi. Uznał je on za niesłuszne, gdy - głównie na gruncie filozofii - starał się dokładniej poznać fenomen religii. Zob. C. Białobrzeski, Szkic autobiograficzny i uwagi o twórczości naukowej, dz. cyt., s. 75.

43 Zob. C. Białobrzeski, Podstawy poznawcze fizyki świata atomowego, Warszawa, 1984, s. 238279. Więcej na temat związku między wprowadzoną przez Białobrzeskiego kategorią potencjalności a teizmem: L. Kostro, La philosophie de la physique de Czesław Białobrzeski et ses relations avec la philosophie aristotélicienne, Roma 1969, s. 83.

44 Niestety, Białobrzeski nie podaje ich precyzyjniejszej charakterystyki. 
które powstały w historii ludzkości, za najdoskonalszą (także w tym aspekcie) uważa on chrześcijaństwo ${ }^{45}$.

Należy w tym miejscu zwrócić uwagę na jeszcze jeden, bardzo interesujący punkt, w którym spotykają się, zdaniem Białobrzeskiego, nauka i religia. Jest on szczególnie istotny w kontekście faktu funkcjonowania człowieka w społeczeństwie. Warszawski fizyk zauważa, że w życiu społeczeństwa działają czynniki, które sytuują się poza możliwościami opisu naukowego. Są to - według niego - między innymi wiara w sprawiedliwość i konieczność poświęcenia dążeń egoistycznych w imię dobra wspólnego, w szczególności przyszłych pokoleń. Białobrzeski dobitnie podkreśla, że żadna nauka, pozostając w obszarze swych kompetencji, nie jest w stanie przedstawić konkretnemu człowiekowi przekonujących argumentów, mogących skłonić go do podporządkowania się czemuś, co stoi ponad nim (społeczeństwo i jego dobro) i poświęcenia swojego egoizmu. W tym miejscu, jego zdaniem, rozpoczyna się rola religii, która - jak zaznacza - ma za zadanie ukształtowanie w człowieku przekonania, że dobro i rozum (racjonalność) mogą być oceniane jako najwyższe wartości i panują także w najbardziej fundamentalnych warstwach wszechświata. Realizacja dobra, postrzegana jako wartość duchowa, wymaga zatem decyzji jednostki, a argumentów za takimi, a nie innymi wyborami, zwłaszcza w kontekście życia społecznego, dostarcza - zdaniem Białobrzeskiego - właśnie religia. Samo dążenie do prawdy, będące - jak wcześniej wspomniano - w opinii warszawskiego fizyka cechą charakterystyczną nauki, nie jest wystarczające w zderzeniu z życiem społecznym. Wydaje się zatem, że religia pełni tutaj funkcję uspołeczniającą ${ }^{46}$. Trzeba przyznać,

45 Zob. C. Białobrzeski, Szkic autobiograficzny i uwagi o twórczości naukowej, dz. cyt., s. 76. Fizyk podkreśla także, że tylko w chrześcijaństwie widzi wciąż dynamikę kulturotwórczą, która oparła się upadkowi cywilizacji grecko-rzymskiej. Nie precyzuje jednak, czy i jaki jest związek tej dynamiki z dynamiką nauki nowożytnej, powstałej przecież w europejskim kontekście kulturowym (z ogromny wpływem chrześcijaństwa). Zob. C. Białobrzeski, Nauka i kultura, dz. cyt., s. 23.

${ }^{46} \mathrm{~W}$ ten sposób Białobrzeski sprzeciwia się wyrugowaniu z życia społecznego religii w imię rzekomej skuteczności nauk i ze względu na ich rozwój, oraz obdarzenia ich ostatecznym autorytetem, także w sprawach społecznych. Zob. C. Białobrzeski, Religia i nauka, dz. cyt., s. 8-9. Na wagę problematyki etycznej, zarówno w kontekście edukacji, jak i pracy naukowej, zwracał uwagę także Władysław Natanson, m.in. w: W. Natanson, Nauka wobec świata. Przemówienie wygłoszone w dniu 
że jest to dość interesujący punkt styku w relacji nauka-religia, punkt zupełnie nieoczekiwany, o konsekwencjach doniosłych dla życia społecznego. Jest to także wyraz całościowego oglądu rzeczywistości, jaki usiłuje wypracować Białobrzeski. Znajduje się w nim - jak można zauważyć miejsce na każdą aktywność człowieka oraz próby określenia relacji między tymi aktywnościami (w tym przypadku relacji między nauką a wiarą). Czyni to z Białobrzeskiego myśliciela bardzo oryginalnego, szukającego jak najlepszych narzędzi - lub, jak sam zapewne by to określił - schematów pojęciowych do jak najgłębszego zrozumienia i opisu rzeczywistości.

\section{Podsumowanie}

Dorobek polskich myślicieli pierwszej połowy XX wieku związanych z naukami przyrodniczymi wciąż stanowi interesujący obszar badawczy. Recepcja nowych teorii fizycznych i nowych trendów w nauce, bogactwo filozoficznego namysłu nad nimi i próby osadzania wyciągniętych wniosków w kontekście szeroko rozumianej kultury (a więc obejmującej także problematykę edukacji, popularyzacji oraz niektóre aspekty społeczne) stanowią ich cechę charakterystyczną, choć oczywiście nie we wszystkich przypadkach. Wydaje się, że spuścizna ta w dużej mierze pozostaje nieznana, jakkolwiek pewne próby, mające na celu wydobycie bogactwa myśli polskiej tego okresu, były już podejmowane i nadal mają miejsce ${ }^{47}$.

W przypadku Czesława Białobrzeskiego można zaryzykować stwierdzenie, że mamy do czynienia $\mathrm{z}$ myślicielem wyjątkowym. Zaprezentowane powyżej poglądy dotyczące relacji nauka-religia można uznać za niezwykle interesujące, niejednokrotnie wyprzedzające epokę. Warszawski fizyk raczej unika sytuacji konfliktu, bierze także pod uwagę odmienność obu sfer intelektualnej działalności człowieka, nie wpadając przy tym w zbyt łatwy dyskordyzm (separację). Podkreślenia

7 października 1922 podczas uroczystości inauguracji roku akademickiego przez Dra Władysława Natansona, Rektora Uniwersytetu Jagiellońskiego, Warszawa 1922.

47 Jedno z najlepszych opracowań w tym zakresie stanowi: P. Polak, Byłem Pana przeciwnikiem [profesorze Einstein], Kraków 2012. Warto także wspomnieć o serii: Krakowska filozofia przyrody w okresie międzywojennym, red. M. Heller i in., t. 1-3, Tarnów 2007. 
wymagają tutaj opisane w niniejszej pracy punkty styku nauki i religii, którym nadaje on wyraźnie eksplikacyjny charakter ${ }^{48}$, oraz - co stanowi oryginalność myśli Białobrzeskiego - wzajemne ich uzupełnianie się, także w kontekście społecznym. Intrygujące są także jego próby połączenia w spójną całość wysiłków intelektualnych człowieka w zakresie religii, filozofii i nauki, przy jednoczesnej świadomości ich odmienności. Powstaje tutaj pytanie o podobieństwa i różnice w zakresie wizji relacji nauka-religia w przypadku Czesława Białobrzeskiego i Michała Hellera. Temat ten może stanowić interesujące pole przyszłych badań.

Na zakończenie wypada zwrócić uwagę na pojęcie religii u Białobrzeskiego. Wyrazem postawy religijnej można u niego określić wiarę w możliwość dotarcia do prawdy ${ }^{49}$. Fakt ten warszawski fizyk uważa - jak już wspomniano - także za fundamentalny punkt styku między nauką i wiarą. Nie sposób oprzeć się jednak wrażeniu, że - w świetle wcześniejszych rozważań - pojęcie religii ma tutaj charakter naturalny i bardzo ogólny, o czym świadczą wypowiedzi dotyczące związków prawdy i piękna ${ }^{50}$, a nade wszystko wspomnianego już, swoistego misterium doświadczanej i badanej rzeczywistości. Nawet w Szkicu autobiograficznym Białobrzeski docenia chrześcijaństwo jako religię, która w sposób najdoskonalszy sprzyja wytwarzaniu dóbr duchowych. Wydaje się zatem, że jest ona dla niego raczej elementem sfery doświadczania wartości (o charakterze psychologiczno-socjologicznym), niż możliwością wejścia w relację z Istotą Transcendentną, która nie tylko jest źródłem wartości (Prawdy, Dobra i Piękna), ale też zbawia ${ }^{51}$.

48 Wyraża się to m.in. w tym (co jest cechą charakterystyczną systematyki Lamberta, która nie wyklucza jednak analogicznej systematyki Barboura), że pozwala on prawomocnie wybrzmieć zarówno tezom naukowym, jak i religijnym, przy czym - dostrzegając ich odmienny charakter - żywi przekonanie, że mogą one wymieniać treści swoich twierdzeń w sposób bardzo owocny i akceptowalny przez obie strony. Zob. C. Białobrzeski, Religia i nauka, dz. cyt., s. 13.

49 Dotyczy to również wiary w prawomocność wartości, które nie mają charakteru tylko poznawczego.

50 Zob. np. C. Białobrzeski, Religia i nauka, dz. cyt., s. 15.

51 W kontekście relacji nauka-religia, a zwłaszcza możliwych oddziaływań teologii i fizyki współczesnej, bardzo interesujące właśnie w kontekście zbawczego działania Boga są uwagi Christophera J. Ishama, który stwierdza, że w tym zakresie tej tematyki trzeba będzie poczekać bardzo długo, aby 


\section{Bibliografia}

Barbour I. G., Ways of Relating Science and Theology, w: Physics, Philosophy, and Theology: A Common Quest for Understanding, ed. G. V. Coyne S.J. i in., Vatican City State 1988, s. 21-48.

Białobrzeski C., Nauka i kultura, w: Kultura i nauka, praca zbiorowa, Warszawa 1937, s. $1-33$.

Białobrzeski C., Nauka ścisła o przyrodzie na tle ogólnych wartości kultury, Kraków 1935.

Białobrzeski C., Podstawy poznawcze świata atomowego, Warszawa 1984.

Białobrzeski C., Religia i nauka, „Nauka Polska. Jej potrzeby, organizacja i rozwój” 13 (1930), s. 1-15.

Białobrzeski C., Rzeczywistość w ujęciu przyrodoznawstwa, „Przegląd Naukowy i Pedagogiczny" 1 (1916) nr 1, s. 29-43.

Białobrzeski C., Syntetyczny rozwój pojęć Fizyki, „Przegląd Filozoficzny” 40 (1937) nr 1, s. 8-18.

Białobrzeski C., Szkic autobiograficzny i uwagi o twórczości naukowej, „Nauka Polska. Jej potrzeby, organizacja i rozwój” 6 (1927), s. 49-76.

Heller M., Nowa fizyka i nowa teologia, Kraków, 2015.

Isham C. J., Creation as a Quantum Process, w: Physics, Philosophy, and Theology: A Common Quest for Understanding, ed. G. V. Coyne S.J. i in., Vatican City State 1988, s. 375-405.

James W., The Will to Believe, „The New World” 5 (1896), s. 327-347.

Krakowska filozofia przyrody w okresie międzywojennym, red. M. Heller i in., t. 1-3, Tarnów 2007.

Kostro L., La philosophie de la physique de Czesław Białobrzeski et ses relations avec la philosophie aristotélicienne, Roma 1969.

Lambert D., Ryzykowne spotkanie teologii z nauką, Kraków 2018.

Motycka A., Czesław Białobrzeskis Conception of Science, w: Polish Philosophers of Science and Nature in the 20th Century, ed. W. Krajewski, Amsterdam-New York, s. 188-195.

fizyka miała coś wartościowego do powiedzenia. Por. C. J. Isham, Creation as a Quantum Process, w: Physics, Philosophy, and Theology: A Common Quest for Understanding, dz. cyt., s. 405. 
Natanson W., Nauka wobec świata. Przemówienie wygłoszone w dniu 7 października 1922 podczas uroczystości inauguracji roku akademickiego przez dra Władysława Natansona, Rektora Uniwersytetu Jagiellońskiego, Warszawa 1922.

Poincaré H., Dernières pensées, Paris 1913.

Polak P., Byłem Pana przeciwnikiem [profesorze Einstein], Kraków 2012.

Polak P., Spór wokót teorii ewolucji sprzed stu lat, „Zagadnienia Filozoficzne w Nauce” 41 (2007), s. 56-90.

Sawicki S., Cz. Białobrzeski jako filozof przyrody, „Zagadnienia Filozoficzne w Nauce” 7 (1985), s. 28-42.

Twarowska J., Zagadnienia z zakresu filozofi fizyki i filozofii przyrody u Czesława Białobrzeskiego, „Studia Philosophiae Christianae” 5 (1969) nr 2, s. 141-158.

Wojtysiak W., Panenteizm. W zwiazkku z pogladami Józefa Życińskiego, Charlesa Hartshorne’a i innych przedstawicieli zwrotu panenteistycznego, „Roczniki Filozoficzne” 60 (2012) nr 4, s. 313-337.

Wszołek S., Racjonalność wiary, Kraków 2003.

\section{Abstrakt}

\section{Przyczynek do badań nad myślą Czesława Białobrzeskiego: wizja relacji między nauką i religią}

Prezentowana praca ukazuje mało znany aspekt myśli Czesława Białobrzeskiego, jednego z najwybitniejszych polskich fizyków pierwszej połowy XX wieku. Relacje między nauką a religią stanowią interesujący punkt przemyśleń Białobrzeskiego, stanowiąc element w precyzyjnie konstruowanym, ogólnym opisie rzeczywistości. Godnym podkreślenia jest także niezwykle nowoczesny charakter spostrzeżeń polskiego fizyka w tym zakresie. Niemniej warta podkreślenia jest próba usytuowania relacji nauka wiara w kontekście społecznym.

\section{Słowa kluczowe}

relacje nauka-wiara, Czesław Białobrzeski, religia, nauka, fizyka 


\section{Abstract}

\section{A contribution to research on the thought of Czesław Białobrzeski:}

\section{The vision of the relationship between science and religion}

This paper presents not very-well known aspect of Czesław Białobrzeski's ideas, who was one of most prominent physicists in Poland in first half of XX Century. The relations between science and religion are very interesting subject of his reflection. It is also an element of his general description of reality, the description of very precise construction. The very modern character of remarks of the polish physicist in this area is also to be emphasized, as well as an attempt of location of relations between religion and science in social context.

\section{Keywords}

Science-religion relations, Czesław Białobrzeski, religion, science, physics 